\title{
Painting with gold: gilders in Northern Alentejo in the 17th and 18th centuries
}

\author{
Patrícia Alexandra Rodrigues Monteiro \\ Faculdade de Letras da Universidade de Lisboa, ARTIS/Instituto de História da Arte/Lisboa, Portugal \\ patriciamonteiro76@gmail.com
}

\begin{abstract}
This article will demonstrate that the artistic context in the North Alentejo region, very dynamic in the 16th century and enriched by the presence of both national and international artists, evolved slowly during the late 17 th and 18th centuries to a reality marked mainly by the activity of local painters, most of them unknown, which became increasingly versatile, working in oil painting, fresco and also gildings. To better characterize this reality, some examples will be presented of artists who worked in various techniques as proved by documentary evidences. The materials now presented were a relevant contribution for the project "Gilt Teller: an interdisciplinary multi-scale study of gilding techniques and materials in Portugal, 1500-1800".
\end{abstract}

\section{Pintar com ouro: douradores no Norte Alentejo nos séculos XVII e XVIII}

\section{Resumo}

Este artigo irá demonstrar que o contexto artístico na região do Norte Alentejo, muito dinâmico no século XVI e enriquecido pela presença de artistas quer nacionais quer internacionais, evoluiu lentamente durante o final do século XVII e todo o século XVIII para uma realidade marcada principalmente pela atividade de pintores locais, a maioria deles desconhecidos, que se tornaram cada vez mais versáteis, trabalhando em pintura a óleo, a fresco e, também, em douramentos. Para melhor caracterizar esta realidade serão apresentados alguns exemplos de artistas que trabalharam em várias técnicas como o comprovam os testemunhos documentais. Os materiais agora apresentados configuraram um contributo relevante para o projeto Gilt Teller: um estudo interdisciplinar multi-escala das técnicas e dos materiais de douramento em Portugal, 1500-1800.

\section{Keywords}

\section{Gilding}

Northern Alentejo

Painters

Gilders

\section{Palavras-chave}

Douramentos

Norte Alentejo

Pintores

Douradores 


\section{Introduction}

The History of Art in Northern Alentejo depends mainly on the biographies of the artists that worked in the region, on the joint activities maintained between artists, and on their working methods. This becomes even more evident knowing the importance that the gilded carved wood production had in this Portuguese region, specially in the final decades of the 17th century and throughout the whole of the 18th century [1].

To better understand this reality we need to look back to the artistic context of the 16th century. Many of the carvers and painters/gilders working on that period tended to focus their activity around the ongoing works of major importance, as was the case for the Elvas and Portalegre cathedrals. However, it was only in the 17th and especially in the 18th century that workshop gilding production flourished.

The presence of important national artists working over three centuries in this region proves the existence of a well informed clientele, eager to hire the best hand labour available. Despite this fact, what best characterized the local production during the modern period was the existence of versatile regional artists, capable of responding to an immense variety of orders. Gilding practice, for example, was something that was immensely intensified from the end of the 17th century onwards, to the same extent that contract orders from religious? brotherhoods and sisterhoods for gilded altarpieces multiplied [2]. Slowly, the painter/gilder category was emphasized, even exceeding the fresco painter, for centuries distinguished as a highly prestigious category amongst painters [3].

The artists that worked with carvers in the majority of altarpieces were mostly oil and tempera painters, simultaneously gilding altars, images, gratings, easel paintings and mural paintings. It is this multiplicity of skills shown by the artists that makes the artistic context in the late 17th and early 18th centuries so interesting. This reality is reflected in the contracts signed between artists and patrons, and that can now provide new data to be analysed by scientists.

\section{Artistic context in Northern Alentejo between the 16th and 18th centuries}

During our $\mathrm{PhD}$ research concerning mural painting in Northern Alentejo, we were able to find several documents concerning gilded altars and partnerships between artists in this region of our country. In some cases, it was possible to confront that information with the remaining gilded altars, and therefore contribute with relevant data to the team involved in the project Gilt Teller.

The artists who worked in the region currently under the Portalegre district are still largely unknown. During our survey of documental sources we paid much attention to work contracts included in the books of the
Notary Offices. In the district's fifteen municipalities it was possible to survey a total of 804 books. The county with more information gathered was Elvas, on the eastern border. In the end it was possible to collect a total of 350 artists' names (masons, sculptors, architects, painters and gilders) working in Northern Alentejo between the late 16th and the 18th centuries. From those, 27 were painters and 8 of them were specifically identified as painters/ gilders.

The survey of documental sources allowed us to understand two distinct but complementary realities: on the one hand, the existence of regional artists, with a relatively low mobility within their geographical places of origin (Elvas, Portalegre, Arronches); on the other hand, the presence of artists from larger and more distant urban centres (Lisboa, Évora, Badajoz). The transit of renowned artists into peripheral territories (Luis de Morales, Simão Rodrigues, Domingos Vieira Serrão, José de Escovar, Diogo Vogado, Bartolomeu Sánchez) is evidence of a dynamic reality, where local clients valued the presence of highly skilled hand labour.

There was, however, another dimension, more difficult to characterize, in which we can include the local artists, still unknown in the majority of cases, possessing a very diverse range of qualifications and assuming, individually or in partnerships, an eclectic set of demands.

Many of the carvers and painter/gilders that worked in the late 16th century and the first quarter of the 17th century tended to focus their activity around ongoing works of major importance, such as the Elvas and Portalegre cathedrals. During this period, there were many painters of excellence who arrived, for example, in Portalegre, coming from other parts of the country to work in what is considered, today, to be the most extensive mannerist art gallery in the country: the cathedral. Besides Luis de Morales, called The Divine, and his collaborators, also Simão Rodrigues and Fernão Gomes worked on the artistic campaigns of the altarpieces distributed within the building [4].

Despite all the activity related with the Portalegre cathedral, the volume of documentation for the 17th and 18th centuries shows that there was a transformation in the context of the workshop order. The first relevant fact is the importance now given to the painter/gilder. Although this category was not strange to most artists of the 16th century, its relevance intensified from the 17th to the same extent that both religious sisterhoods and brotherhoods multiplied their orders for altarpieces for chapels and churches. Slowly, the painter/gilder reached a very high distinction, coinciding with fresco painters slowly losing ground in the work context of artistic campaigns.

The expression fresco painting does not disappear from the (archival) documentation, although its meaning is not clear. The fact that many of these painters could run gildings and paintings simultaneously (on both altarpieces and ceilings), made the definition of pictorial techniques within the documentation begin to blur. From the patron's point of view, the use of the same hand labour for the 
gilding of an altar, a vault, or both was more financially convenient, thus justifying the high number of orders that some painters/gilders benefited from.

\section{Artists and partnerships in Northern Alentejo}

To better explain what the artistic context in Northern Alentejo was, we will present examples of three different work situations: a large workshop led by the dominant figure of a painting master (José de Escovar); the partnerships between Simão Rodrigues and Domingos Vieira Serrão and between Diogo Vogado and Bartolomeu Sánchez, which are examples of artists working together in works of a higher quality level; local workshops of unknown painters/gilders, working individually or in partnerships with other artists.

One of the last fresco painters in Northern Alentejo was José de Escovar (working between 1585-1622), whose activity marked the transition between the 16th and the 17 th centuries. Within his workshop it is well known that, besides fresco, he also executed oil painting, tempera and gildings. In 1603, he signed a contract with the Confraria de Nossa Senhora das Almas, in Vila Nova da Baronia, for the fresco paintings of the chapel walls and vault [5] (Figure 1). Besides that, he was supposed to oil paint the panel of the altarpiece and to gild the altarpiece itself. This is a good example of an artist responsible for a whole decorative set.

Similar examples of Escovar's versatility can be found only in documents, for many of his works no longer exist, and were replaced by modern campaigns. That's the case in the church of the Santa Clara Convent, in Elvas. The artist's connection with this town remained strong throughout the first decade of the 17th century, while he worked in large apparatus campaigns linked to the ecclesiastical clientele or the nobility. In July 1610, Escovar is in Elvas to run the pictorial coating and gilding programme of the main chapel of the Santa Clara Convent church "with fresco colors [and] the arch of the main chapel will be gold over mordant of oil and inks" [6]. This work was replaced, about a century later, by the work of an Elvas painter/gilder called Agostinho Mendes.

Perhaps the best testimony to the existence, in Northern Alentejo, of highly qualified hand labour involved in both mural paintings and gildings is the presence, registered several times, of the team Simão Rodrigues (active ca. 1583-1629) and Domingos Vieira Serrão (active ca. 15701632) [7]. It is known how fruitful their activity was, mainly in oil painting, as proved by multiple working contracts throughout the country from Lisbon to Coimbra, Leiria, Santarém, Évora, Portalegre and Elvas.

Simão Rodrigues was the first to arrive in Elvas (c. 1600), to paint the altarpiece of the S. Domingos Convent church. In 1615, at the request of bishop D. Rui Pires da Veiga, he returned to this city accompanied by Domingos Vieira Serrão. Their job was to carry out pictorial decorations within the Elvas cathedral, namely in the Santíssimo Sacramento chapel and in the sacristy, following pre-existent models of two Lisbon churches [8]. The ceiling of this sacristy (completely whitewashed today) followed the model of the vault of the Hospital Real de Todos-os-Santos, in Lisbon. The paintings in that vault (later destroyed in a fire) had been executed by the two painters themselves just a couple of years earlier (1613), representing one of Lisbon's most famous pictorial campaigns [9]. The initial project was a painting directly inspired in models of the Italian Mannerism with simulated oil paintings inserted in gold leafed geometrical panels.

Domingos Vieira Serrão returned to the Elvas Cathedral one last time, in 1631. The work was, once again, of high importance: the bishop Sebastião Matos de Noronha hired him "to repair, gild and plaster the whole interior of the cathedral [...] and the ceiling with golden brutesco" [10]. The work included the complete coating of the churches' three aisles, columns, the arch of the main chapel with golden brutesco, a decorative painting category that derived from the grotesque with which the painter was very familiar [11].

Two other painter/gilders working together were Diogo Vogado (active ca. 1608- $\uparrow 1652$ ) and Bartolomeu Sánchez (active ca. 1612-†1641). In 1628, the artists were contracted to paint the ceiling and the altar of the Santíssimo Sacramento Chapel in the Elvas Cathedral.

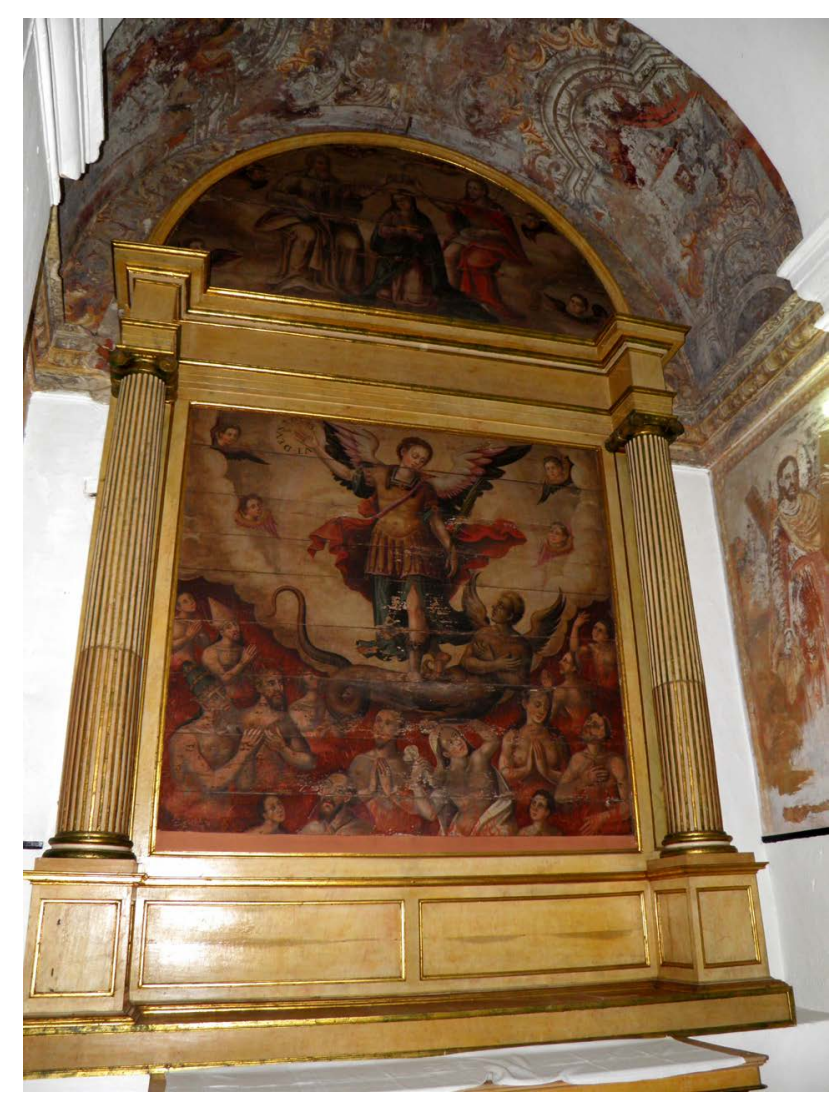

Figure 1. Capela das Almas, Vila Nova da Baronia, 1603. José de Escovar (active ca. 1585-1622). 
The contract established, besides the gilding of the chapel ceiling, works for the altarpiece and the saints present therein: "the altarpiece will be cleaned and washed of all the dust and pasted with very weak glue [...] thereafter it will receive five coats of thick plaster the oldest possible because if it's done otherwise it will not be a good work" [12].

Despite the relevance of these painters, or of their achievements, they were not who best characterized the artistic production in this region. To understand the Art History of Northern Alentejo, it's important to analyse the artistic journey of some of the painters/ gilders that never left this region, working with carvers and carpenters, gilding or painting ceilings, arches and columns. This happened with a great number of artists such as Afonso Vaz (1657-1693), António dos Santos (1674-1753), António Soeiro da Silva (1680-1692), Agostinho Mendes (1689-1740), Agostinho Correia Dinis (1692-1725), Bruno de Azevedo (1723-1729) or Manuel Pereira Gavião (1726-1753) just to mention a few. The dates presented correspond exclusively to the period when their involvement in artistic campaigns could be tracked through documental evidences. Despite that, we know that several of these artists extended their activity through the 18 th century, maintaining their working methods. Two of the still unknown although best-documented artists working in Northern Alentejo in the transition from the 17 th to the 18th century were Afonso Vaz and António Soeiro da Silva.

Afonso Vaz was a local painter who developed his activity in gilding, oil painting and fresco between Elvas, Castelo de Vide and Portalegre. One of his works that arrived to this day is the gilding of the tabernacle, saints and angels from the main altar of Nossa Senhora da Consolação, belonging to the Church of S. Lourenço in Portalegre, a work that began in 1673, and for which he received over 72.000 réis [13] (Figure 2).

About two years later, on October 17th 1679, Vaz is quoted in another contract for the gilding of the Santíssimo Sacramento altarpiece, belonging to the Castelo de Vide church. The document [14] stated that he had to paint "the ceiling and the friezes with gold [...] and oiled with the finest paint that the work required". The contract also specified that the stone friezes were to be plastered and "painted with good paint and fresco". It is the first time that another assignment is given to this painter besides the gilding of altarpieces, even though the nature of the program itself is not clear. The document mixes references like fine oil paint, gold, fresco and plastered walls. Like in Escovar's case, almost eight decades earlier, in this campaign it is the same artist that should perform the entire decoration works within the same space, proofing his versatility.

Another artist, António Soeiro da Silva, is mentioned in several contracts for painted and gilded altarpieces often associated with painted ceilings (the so-called brutesco paintings) and walls. In 1680, he signs a contract with the brotherhood of Nossa Senhora da Boa
Morte, in the Castelo de Vide main church, for gilding their altarpiece, as well as for the "fresco painting of the main chapel" and the oil painting of its iron bars [15]. Throughout the document, Soeiro is always described as a painter/gilder. He continued his gilding activity until 1692, when he worked in the altarpiece of the Nossa Senhora dos Remédios Church, in the same town of Castelo de Vide, and that, most likely, is still the one that exists in that same building. The work contract establishes that "the altarpiece will be gild with gold of the highest value that can be found, as will be the niches $[\ldots]$ and the angels, their hair and wings, with a thin final polishing" [16].

To these two examples we could add many others. For example, the contract signed by the painter/ gilder Agostinho Mendes in 1706 with the Santíssimo Sacramento brotherhood of the Elvas Cathedral for the complete painting of their chapel (again with colored brutesco) and finally the altarpiece gilding [17]. Or the well known (already mentioned) Manuel Pereira Gavião with a strongly documented activity as a gilder throughout Alentejo that worked closely with the Lisbon painter António Pimenta Rolim in oil paintings over ceilings, combining stylistic influences of Vincenzo Baccherelli with the never ending brutesco motives. In 1753, he signed a contract for teaching the trade of painter and gilder to a young pupil, António José, proving that these techniques remained together within the 18th centuries artists background [18].

\section{Conclusions}

At the end of our brief essay, there are a few notes that require our attention.

The first thing is to acknowledge that there were moments of enormous artistic dynamism in the Northern Alentejo region, with the presence of artists of national importance. The presence of renowned artists over three centuries in this region of the country proves the existence of well-informed clienteles, anxious to hire the best hand labour available.

However, in the transition from the 17th to the 18th century the painter/gilder gained more visibility. Regardless of the influences that those major artists may have left, both documents and some works that survived to our days show us a different reality, based on the versatility of local hand labour and its ability to respond to various requests. Painters are now essentially oil painters, simultaneously gilding altars, images, gratings and also painting vaults with countless brutesco compositions, less demanding, perhaps, in what concerned technical skills. The professional relations between artists of different trades in Northern Alentejo are still far from being completely understood. Further documental investigations, as well as an interdisciplinary approach are fundamental for the global comprehension of the gilding phenomenon in Portugal. 


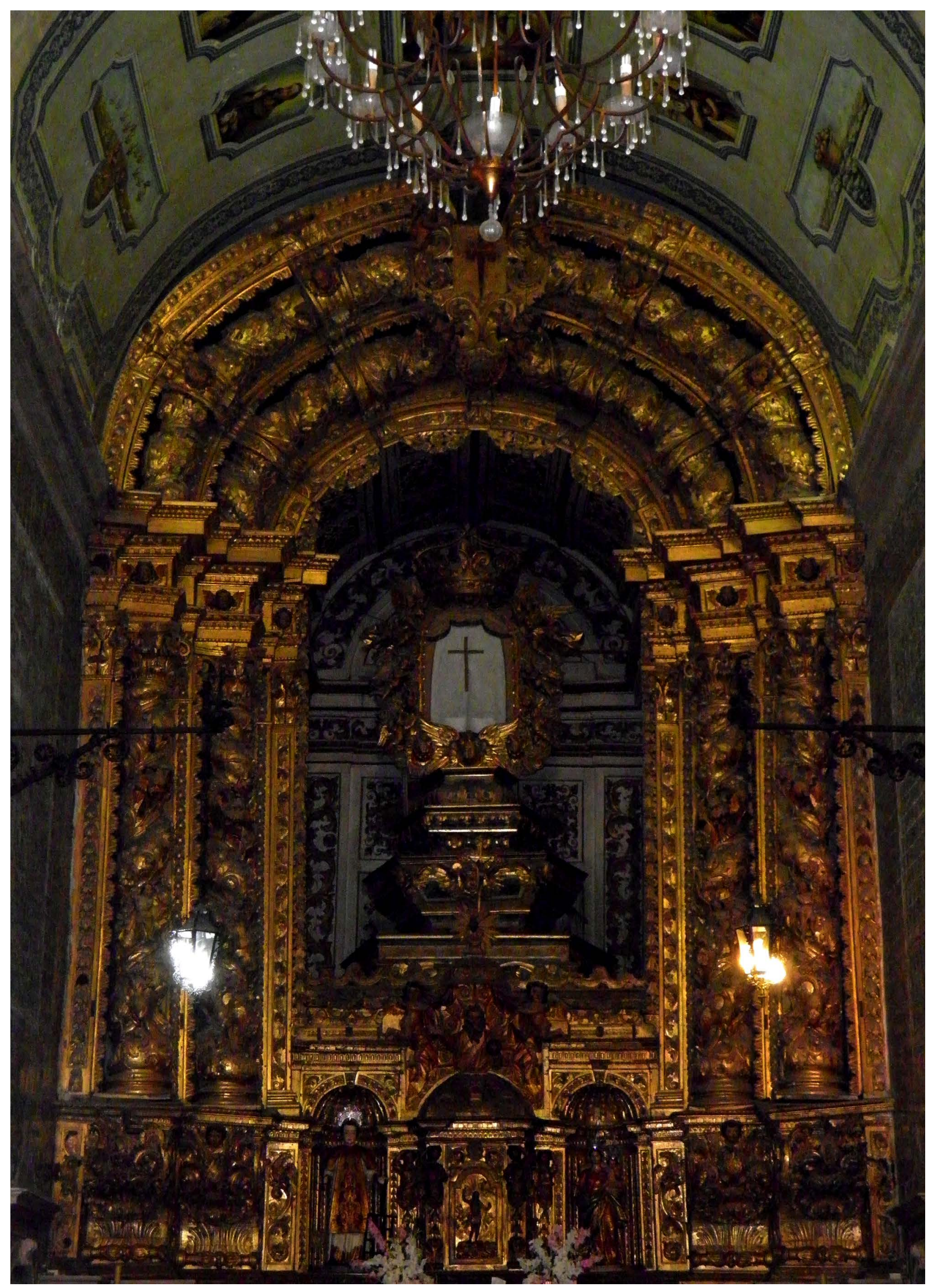

Figure 2 Altarpiece of S. Lourenço Church (Portalegre). Afonso Vaz (active ca. 1657-1693). 


\section{Acknowledgements}

The author wishes to thank several institutions and individuals that made this $\mathrm{PhD}$ possible, specially the Foundation for Science and Technology (FCT) for all the support given throughout the investigation (FCT SFRH/BD/45326/2008). Also to Dr. Vitor Serrão for sharing the discovery of the contract of José de Escovar with the Confraria das Almas (1606). Finally, special thanks are due to Dr. Irina Sandu, principal researcher of the project Gilt Teller: um estudo interdisciplinar multi-escala das técnicas e dos materiais de douramento em Portugal, 15001800, project PTDC/EAT-EAT/116700/2010, financed by FCT.

\section{References}

1 Monteiro, P., 'A pintura mural no Norte Alentejo (séculos XVI-XVIII): Núcleos temáticos da Serra de S. Mamede', $\mathrm{PhD}$ dissertation, University of Lisbon, Lisbon (2012), http://hdl.handle.net/10451/8454.

2 Ferreira, S., 'A talha barroca de Lisboa (1670-1720), Os artistas e as obras', $\mathrm{PhD}$ dissertation, University of Lisbon, Lisbon (2009), http://hdl.handle.net/10451/2007.

3 Holanda, F., Da Pintura Antiga [1548], Lisboa, Imprensa Nacional-Casa da Moeda (1983).

4 Serrão, V., 'A actividade do pintor Luís de Morales, el Divino em Elvas e Portalegre (1576-1585)', A Cidade Revista Cultural de Portalegre 12 (1998), 45-70.

5 'Contrato entre a Confraria das Almas da Matriz de Vila Nova da Baronia e o pintor José de Escovar para a pintura a fresco e a óleo da sua capela, bem como o douramento do seu retábulo', manuscript, Arquivo Distrital, Evora, L. ${ }^{\circ} \mathrm{s}$ 330-331 (1606) 83-87, 40-42 v.

6 'Contrato entre o Bailio Rui de Brito e o pintor José de Escovar para a pintura a fresco da capela-mor do Convento de Santa Clara de Elvas e de algumas divisões na casa do encomendante', manuscript, Arquivo Distrital, Portalegre, CNELV04/001/Cx. 18, L. 27 (1610), 124v.-126v.

7 Gusmão, A., Simão Rodrigues e seus Colaboradores, Lisboa, Artis (1957).

8 'Contrato entre o bispo de Elvas e os pintores Simão Rodrigues e Domingos Vieira Serrão para a pintura da sacristia e Capela do Santíssimo Sacramento da Sé de Elvas', manuscript, Arquivo Distrital, Portalegre, CNELV04/001/ Cx. 19, L.' 35 (1615) 34v.

9 Markl, D.; Serrão, V., 'Os tectos maneiristas da Igreja do Hospital Real de Todos-os-Santos (1580-1613)', Boletim Cultural da Assembleia Distrital de Lisboa 86(1) (1980) 161-215.

10 'Contrato de pintura das abóbadas da Sé de Elvas, assinado entre o bispo D. Sebastião Matos de Noronha e o pin- tor Domingos Vieira Serrão', manuscript, Arquivo Distrital, Portalegre, CNELV06/001/Cx. 106, L. ${ }^{\circ} 64$ (1631) 95v.-99.

11 Serrão, V., 'A pintura proto-barroca em Portugal, 16121657 ', PhD dissertation, University of Coimbra, Coimbra (1992).

12 'Contrato entre D. Maria do Quintal e os pintores de Évora Diogo Vogado e Bartolomeu Sanches para a pintura do tecto da capela do Santíssimo Sacramento, na Sé de Elvas', manuscript, Arquivo Distrital, Portalegre, CNELV04/001, Cx. 25, L. ${ }^{\circ} 58$ (1628) 96v.-99v.

13 'Testamento Cerrado do Reverendo Prior Manuel Nunes de Avelar, a propósito das obras a realizar na Capela-mor da Igreja de S. Lourenço de Portalegre', manuscript, Arquivo Distrital, Portalegre, TCPTG, L. ${ }^{\circ} 5241$ (1665-1675) 217v.$-218 \mathrm{v}$.

14 'Escritura de quitação dada por José Carvalho, pintor de Portalegre, à obra do douramento do retábulo do altar de Nossa Senhora do Rosário, da matriz de Castelo de Vide', manuscript, Arquivo Distrital, Portalegre, CNCVD01/001, Cx. 18, L. 66 (1679) 13-15.

15 'Contrato de douramento do retábulo de Nossa Senhora da Boa Morte na matriz de Castelo de Vide, entre a respectiva confraria e o pintor António Soeiro da Silva bem como a "pintura a fresco do frontispício" e olear as grades da mesma capela', manuscript, Arquivo Distrital, Portalegre, CNCVD01/001, Cx. 18, L. 67 (1680) 82v.-84v.

16 'Contrato celebrado entre as Religiosas do Convento de Jesus de Monforte com o pintor Agostinho Correia Dinis', Arquivo Distrital, Portalegre, CNCVD01/001, Cx. 21, L. ${ }^{\circ} 85$ (1692) 231-232.

17 'Contrato entre a Confraria do Santíssimo Sacramento e o dourador Agostinho Mendes para pintar e dourar a sua capela', Arquivo Distrital, Portalegre, CNELV06/001, Cx. 118, L. ${ }^{\circ} 85$ (1706), 113-115v.

18 'Contrato de ensino com o pintor-dourador Manuel Pereira Gavião', Arquivo Distrital, Portalegre, CNALT01/001/Cx. 8, L. 19 (1753), 11v.-12v.

Received: 2015-07-15

Revised: 2015-12-23

Accepted: 2016-01-05

Online: 2016-01-11

This work is licensed under the Creative Commons Attribution-NonCommercial-NoDerivatives 4.0 International License. To view a copy of this license, visit http://creativecommons.org/licenses/by-nc-nd/4.0/deed.en. 